\title{
Diskursus $\underline{H} u d \hat{u} d$ dalam Studi Hukum Islam (Melacak Evolusi Rumusan $\underline{H} u d \hat{u} d$ )
}

\author{
Junaidi Abdillah \\ (UIN Walisongo Semarang Jl Walisongo 3-5 Semarang, \\ Email: junaidiabdillah02@gmail.com)
}

\begin{abstract}
Abstrak:
Rumusan hudûd yang selama ini ada lebih identik dengan bentuk pidana dan hukuman. Rumusan dan konstruksi yang demikian diakui telah mendistorsikan konsep sebenarnya tentang konsepsi hudûd. Paper ini bertujuan mengupas serta mengelaborasi diskursus hrudûd dalam studi hukum Islam. Disamping itu, tulisan ini juga melacak pergeseran- paradigma terkait konsepsi dan rumusan $\underline{h} u d \hat{u} d$ yang muncul sepanjang sejarah. Tulisan ini menggunakan pendekatan hermeneutika-tematis melalui studi dokumenter bersifat historis elektif-eliminatif. Data akan dibandingkan, dianalisis serta disaring hingga tersisa satu teori yang paling relevan. Paper ini menyimpulkan bahwa diskursus h hudûd dalam hukum Islam telah mengalami pergeseran paradigma (paradigm shift) dari waktu ke waktu. Dan, rumusan hludîd yang identik dengan bentuk-bentuk pidana (al-'uqûbât al-muqaddarah) merupakan ijtihad para fuqahâ' atas tradisi kenabian (Sunnah). Sebagai hasil ijtihad, rumusan hrudîd yang ada merupakan ruang ilmu yang terbuka dengan kritik.
\end{abstract}

\section{Kata Kunci:}

Hudûd, Ijtihad, Evolusi, Studi hukum Islam

\begin{abstract}
:
The formulation of $\underline{h} u d \hat{u} d$ law has been more synonymous with criminal and punishment forms. Such formulations and construct are recognized to distort the true concept of $\underline{h} u d \hat{u} d$. It also implicates on the theoretical debate in Islamic penal law. The main goal of this paper is to explore and elaborate the $\underline{h} u d \hat{u} d$ discourse in the study of Islamic law. This paper is a library research with a hermeneutical approach. The data collection technique used in this research is a documentary study (historical) which is elective-eliminative historic in nature. The analysis methods used in the research are the general methodical elements such as interpretation and deductive-inductive also personal reflection. This paper produces several conclusions: (1)
\end{abstract}


The discourse of hudûd penal in the Islamic criminal law studies has experienced a paradigm shift as a dynamic entity from time to time. And the stipulation of $\underline{h} u d \hat{u} d$ penal is an Islamic Juristic formulation (fuqahä') and (2) As a product of ijtihad, stipulation of $\underline{h} u d \hat{u} d$ or its existence is open with criticism using contemporary epistemology.

\section{Kata Kunci:}

Hudûd, Ijtihâd, Evolution, The Study of Islamic Law

\section{Pendahuluan}

Konsep $\underline{h} u d \hat{u} d$ dalam studi hukum Islam selama ini dinilai final dan dipandang qath'î al-dilâlah. ${ }^{1}$ Padahal, secara faktual empiris, al-Qur'an sebagai sumber utama hukum Islam menggunakan terma hudûd secara fleksibel. Namun demikian, konstruksi itu telah dimapankan oleh para yuristik (fuqahấ) belakangan dengan memunculkan teori haqq Allāh dan haqq adamî. Kondisi ini memunculkan reduksi hakikat $\underline{h} u d \hat{u} d$ yang identik dengan bentuk punishment (pidana) yang bersifat final dan pasti.

Terma $\underline{h} u d \hat{u} d^{2}$ dalam al-Qur'an sejatinya digunakan dengan makna yang luas. Terma ini tidak hanya berkaitan dengan tindak pidana (kejahatan) beserta ancaman sanksinya ('uqûbât) saja, melainkan juga berkaitan dengan pelanggaran terhadap pelaksanaan

1 Konsep qath'î dan zhannî tema yang masuk dalam kajian ilmu ushûl al-fiqh. Sebagaiamana diketahui bahwa teks-teks al-Qur'an terbagi menjadi dua: (1) qath'î aldilâlah, yaitu: teks-teks yang mempunyai arti pasti dan tidak menimbulkan ta'wîl dan pemahaman lain. (2) zhannî al-dilâlah yaitu teks yang menunjuk pada sebuah makna, tetapi masih memiliki kemungkinan untuk di-ta'wîl atau diubah dari makna aslinya kepada makna lainnya. Lihat Abi Bakr Aḥmad al-Râzi al-Jashshâsh, Ahkâm al-Qur'ân, Jilid II (Beirut: Dar al-Fikr, 1993), 5-6.

${ }^{2} \underline{H} u d \bar{u} d$ merupakan bentuk jamak dari kata hadd yang secara etimologi berasal dari akar kata $\tau$ dan $\lrcorner$ yang mempunyai dua makna asal yaitu larangan dan batas (tepi) sesuatu. Jika dikaitkan dengan kata hadd al-sayf atau hadd al-sikkîn maknanya menjadi mengasah mata pedang atau mengasah mata pisau. Dalam makna leksikalnya, hadd (hudud) biasa dimaknai dengan ta'rîf atau undang-undang. Membuat definisi berarti memberikan batasan (dari segi mâni' dan jâmi') pengertian sebuah istilah sehingga term lain tidak termasuk didalamnya. Kaitannya dengan undang-undang sebab undang-undang memberikan batasan aturan terhadap sesuatu atau orang sehingga tidak boleh melanggarnya. Lihat dalam Abu Al-Husain Ahmad bin Faris bin Zakariya, Mu'jam Maqâyis al-Lughah, Jilid II, (Beirut: Dar-al-Fikr, 1399 H. /1979 M.), 3. Lihat pula Ibrahim Mushthafa, dkk., Mu'jam al-Wasith, Jilid I, (Teheran: Maktabah alIlmiyah: t.th.), 7 . 
shalat, puasa, dan perkawinan (thalâq, 'iddah). ${ }^{3}$ Singkat kata, bahwa yang termasuk wilayah $\underline{h} u d \hat{u} d$ dalam al-Qur'an tidak hanya terbatas pada persoalan pidana (jarîmah), melainkan mencakup diskursus lainnya seperti ibadah, perkawinan dan atau kewarisan.

Kendati demikian, terma $\underline{h} u d \hat{u} d$ belakangan telah mengalami reduksi makna. Bahkan mengalami pergeseran paradigma dan konsepsi. Terma hrudûd yang semula luas dan fleksibel, pada gilirannya kemudian identik dengan pengertian dan konstruksi pidana. Utamanya yang berkaitan dengan bentuk-bentuk hukuman atas kejahatan yang telah dijelaskan secara rinci di dalam al-Qur'an dan Sunnah. Muncullah terma hudûd yang identik dengan al-'uqūbāt al-muqaddarah (pidana-pidana yang bersifat pasti). ${ }^{4}$

Berangkat dari uraian di atas maka perlu kajian dan penelitian tentang hakikat $\underline{h} u d \hat{u} d$ dalam studi hukum Islam. Tema ini penting untuk memperjelas peta dan diskursus $\underline{h} u d \hat{u} d$ dalam bingkai studi Islam melalui pertanyaan-pertanyaan, bagaimana konsepsi hudûd dalam al-Qur'an dan al-Sunnah serta Fiqh; bagaimana konstruksi hud $\hat{u} d$ dalam hukum Islam; kapan terminologi h̆udûd identik dengan sanksi pidana yang tetap dan pasti ini muncul; dan bagaimana relevansinya bagi kajian hukum Islam kontemporer. Kajian ini ditulis melalui pendekatan hermeneutika-tematis dengan metode studi dokumenter yang bersifat historis elektif-eliminatif. Artinya, teoriteori pengetahuan tentang $\underline{h} u d \hat{u} d$ yang muncul sepanjang sejarah akan dibandingkan, dianalisis, serta disaring hingga tersisa satu teori yang paling relevan. Untuk analisis menggunakan unsur-unsur metodis umum seperti deduktif-induktif dan refleksi kritis.

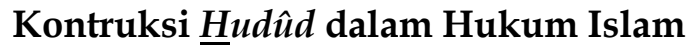

Secara bahasa hudîf merupakan bentuk plural dari kata hadd yang berarti al-man'u yaitu larangan atau pencegahan. Secara istilah, dalam al-Mu'jam al-Wasith, hudûd bermakna sanksi yang telah

3Jika dikaji dengan pendekatan tematik (maudlû'i) terma $\underline{h} u d \hat{u} d$ dalam al-Qur'an tidak hanya berbicara terkait aspek pidana saja. Terma $\underline{h} u d \hat{u} d$ digunakan juga berkaitan dengan hukum perdata (madaniyyah) dan juga berkaitan dengan wilayah ibadah, seperti hudûd-nya shalat. Lihat dalam CD Maktabah Syamilah versi 2014.

4Hasbi Asshiddieqy, al-Islam, Jilid II, (Jakarta: Bulan Bintang, 1977), 506. Lihat juga dalam Abū Zahrah, al-'Uqûbah; al-Jarîmah wa al-'Uqûbah fî al-Islâm (Kairo: Dār al-Fikr al-'Arabī, 1998), 76-78. 
ditentukan dan wajib dibebankan kepada pelaku tindak pidana. ${ }^{5}$ Sementara Butrus al-Busthânî dalam Muhîth al-Muhîtth mendefinisikan hudûd sebagai sanksi yang telah ditentukan dan wajib dilaksanakan secara benar karena Allah. Sanksi hukum ini disebut dengan hadd karena dapat mencegah pelaku dari kegiatan dosa rutin. Batas yang dapat membedakan benda-benda tidak bergerak dari benda-benda lain yang juga tidak bergerak seperti dinding dan tanah-tanah. ${ }^{6}$ Pada perkembangannya kemudian, istilah hudtûd digunakan untuk menyebut pengertian "pidana", khususnya yang berkaitan dengan bentuk-bentuk kejahatan yang dijelaskan secara rinci di dalam alQur'an dan al-Sunnah. Sedangkan bentuk-bentuk kejahatan yang diancam dengan pidana $\underline{h} u d \hat{u} d$ ini disebut dengan jarimah al-hadd (kejahatan yang ada ketentuan hadd-nya). ${ }^{7}$

Hukum pidana Islam, telah menentukan bahwa bentuk pidana terhadap perbuatan-perbuatan kriminal yang masuk dalam kategori pidana hudûd jumlahnya ada tujuh pidana: membunuh, minumminuman keras (memabukkan), mencuri, perampokan, berzina, menuduh orang lain berzina, dan murtad. Selain dari pidana qishāsh, yang merupakan pidana untuk pembunuhan atau melukai seseorang, semua pelanggaran pidana yang lainnya masuk dalam kategori pidana $t a^{\prime} z \bar{\imath} r$. Walaupun mayoritas ulama sepakat dengan pembagian seperti ini namun tidak berarti tidak ada ulama-ulama minoritas yang berpendapat lain tentang kategori pidana $\underline{h} u d \hat{u} d .{ }^{8}$

\section{Diskursus $\underline{h} u d \hat{u} d$ dalam al-Qư'an}

Terma hudûd dalam al-Qur'an digunakan tidak hanya terkait dengan ketentuan bentuk dan sanksi pidana. Istilah hudûd tidak hanya berkaitan dengan al-figh al-jinấî saja melainkan juga digunakan dalam hukum privat Islam. Perceraian (thalâq) misalnya, istilah $\underline{h} u d \hat{u} d$

\footnotetext{
5 Ibrahim Anas dkk, al-Mu'jam al-Wasith (Mesir: Majma' al-Lughah al-'Arabiyyah, 1972), 314

6 Butrus al-Bustânî, Muhîth al-Muhîth; Qâmûs Mutawwal li al-'Arabiyyah (Lebanon: Maktabah Lubnah, 1983), 154

7 Hasbi Asshiddieqy, al-Islam..., 506. Lihat juga dalam Abū Zahrah, al- Uqûbah; alJarîmah wa al- 'Uqûbah fî al-Islâm (Kairo: Dār al-Fikr al-'Arabī, 1998), 76-78.

8 Mohammed S. El-Awa, Punishment in Islamic Law (Indianapolis: American TrusPublications, 1982), 2-3.
} 
untuk batasan-batasan perilaku yang benar bagi suami istri. ${ }^{9}$ Terma hudûd juga merujuk pada aspek ibadah yaitu pujian Allah untuk hamba-Nya yang mematuhi $\underline{h} u d \hat{u} d$ Allah. ${ }^{10}$ Juga digunakan kaitannya dengan denda penebusan (kifârat). ${ }^{11}$ Al-Qur'an tidak menyebut $\underline{h} u d \hat{u} d$ hanya untuk bentuk pidana yang bersifat tetap.

Berkaitan dengan masalah pelanggaran dalam perceraian (thalâq) misalnya, Q.S al-Thalāq 65:1 yang berbunyi:

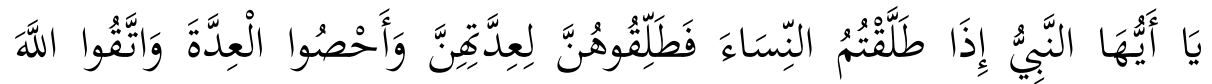

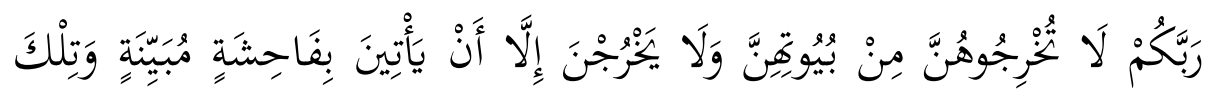
حُدُودُ اللَّهِ وَمَنْ يَتَعَدَّ حُدُودَ اللَّهِ فَقَدْ ظَلَمَ نَفْسَهُهُ...

Hai Nabi, apabila kamu menceraikan isteri-istermu, hendaklah kamu menceraikan mereka pada waktu mereka dapat menjalankan 'iddahnya secara wajar. Dan hitunglah waktu 'iddah itu serta bertawakkalah kepada Allāh Tuhanmu. Janganlah kamu mengeluarkan mereka dan janganlah kamu izinkan mereka untuk keluar kecuali bila mereka mengerjakan perbuatan keji secara terang-terangan. Itulah hukum-hukum Alläh, maka sesungguhnya dia telah berbuat dzalim terhadap dirinya sendiri.

Demikian halnya dengan firman Allāh dalam Q.S al-Nisa' 4: 1314 yang berbunyi:

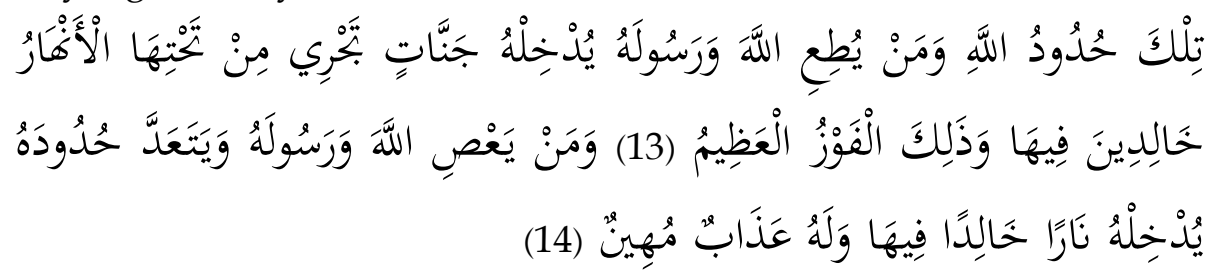

Itulah ketentuan-ketentuan Alläh, dan barang siapa yang mentaati Alläh dan rasulNya maka akan masuk surga yang di bawahnya mengalir sungai-sungai mereka kekal di dalamnya dan yang demikian merupakan kemenangan besar. Dan barangsiapa yang mendurhakai Alläh dan Rasul-Nya serta melanggar ketentuanketentuan-Nya, niscaya Allāh memasukannya ke dalam api neraka sedang ia kekal di dalamnya."

\footnotetext{
${ }^{9}$ Lihat QS 2: 229

${ }^{10}$ Lihat QS 9: 12

11 Lihat QS 58: 3-5
} 
Apabila dipahami lebih dalam, kedua ayat tersebut --tentunya masih terdapat ayat lainnya tentang $\underline{h} u d \hat{u} d--$ membicarakan persoalan $\underline{h} u d \hat{u} d$ terkait dengan bidang perceraian dengan ketentuan masa 'iddah dan juga ayat kewarisan. Artinya, al-Qur'an membicarakan hrudûd tidak terbatas pada persoalan-persoalan jarîmah dan 'uqûbah semata. Dengan demikian, di sini dapat dikatakan telah terdapat penyempitan makna (reduksi) yang dimunculkan oleh para ulama fiqh bahwa hudîd dalam al-Qur'an hanya menyangkut persoalanpersoalan tindak pidana kriminal.

Adapun ayat-ayat yang memuat lafazh $\underline{h} u d \hat{u} d$ dan hakikat makna yang dikandungnya dalam al-Qur'an dapat diklasifikasikan sebagai tergambar dalam tabel sebagai berikut:

Tabel 7

Penggunaan $\underline{H} u d \hat{u} d$ dalam Al-Qur'an

\begin{tabular}{|c|c|c|c|c|}
\hline No. & $\begin{array}{l}\text { Terdapat dalam Surat } \\
\text { dan Ayat }\end{array}$ & Disebut & $\begin{array}{l}\text { Bentuk } \\
\text { Redaksi }\end{array}$ & Maknanya \\
\hline 1. & QS. al-Baqarah 2:187 & 1 kali & حدو دالله & $\begin{array}{l}\text { Larangan- } \\
\text { larangan }\end{array}$ \\
\hline 2. & QS. al-Baqarah 2:229 & 4 kali & حدودالله & $\begin{array}{l}\text { Hukum- } \\
\text { hukum }\end{array}$ \\
\hline 3. & QS. al-Baqarah 2:230 & 2 kali & حدودالله & $\begin{array}{l}\text { Hukum- } \\
\text { hukum }\end{array}$ \\
\hline 4. & QS. al-Nisa' 4:13 & 1 kali & حدودالله & $\begin{array}{l}\text { Ketentuan- } \\
\text { ketentuan }\end{array}$ \\
\hline 5. & QS. al-Nisa' 4:14 & 1 kali & حدوده & $\begin{array}{l}\text { Ketentuan- } \\
\text { ketentuan }\end{array}$ \\
\hline 6. & QS. al-Taubah 97 & 1 kali & اللهود ما انزل & $\begin{array}{l}\text { Hukum- } \\
\text { hukum }\end{array}$ \\
\hline 7. & QS. al-Taubah 9:112 & 1 kali & حدو دالله & $\begin{array}{l}\text { Hukum- } \\
\text { hukum }\end{array}$ \\
\hline 8. & QS. al-Mujadalah 58:4 & 1 kali & حدودالله & $\begin{array}{l}\text { Hukum- } \\
\text { hukum }\end{array}$ \\
\hline 9. & QS. al-Thalaq 65:1 & 2 kali & حدو دالله & $\begin{array}{l}\text { Hukum- } \\
\text { hukum }\end{array}$ \\
\hline
\end{tabular}


Berdasarkan tabel di atas dapat dipahami bahwa tidak satu pun ayat yang menampilkan $\underline{h} u d \hat{u} d$ dalam bentuk kata mufrad (hadd) dan semuanya berbentuk plural yakni hudûd. Hal ini mengisyaratkan kepada kita bahwa hudûd Allāh itu jumlahnya banyak (plural) dan tidak bersifat khusus. Juga, tidak ada satu pun redaksi $\underline{h} u d \hat{u} d$ di atas yang dilekatkan dengan bentuk-bentuk pidananya (al-`uqûhbât).

Menariknya, tidak ada satu pun terma hudîd dalam al-Qur'an yang berkaitan dengan kejahatan pencurian atau perzinahan atau perampokan. Dengan demikian, konstruksi pemahaman yang mengatakan bahwa hudûd identik dengan jarimah dan al-'uqûbât almuqaddarah bertolak belakang dengan kenyataan di dalam al-Qur'an. Dari sekian ayat Al-Qur'an yang membicarakan aspek hrudûd tidak ada satu ayat pun yang berkaitan langsung atau identik dengan tindak pidana (jarîmah) beserta 'uqûbah-Nya. Al-Qur' an menggunakan terma $\underline{h} u d \hat{u} d$ secara umum dan luas untuk segala bidang kehidupan. Pada titik ini menarik mencermati proposisi yang dikemukakan oleh Hashim Kamali:

Kata-kata hadd atau hudûd tidak digunakan di dalam al-Qur'an sebagai hukuman yang wajib dan tetap, sebagaimana diajukan dan ditetapkan pleh para fuqahấ. Dengan mendefinisikan hadd sebagai hukuman yang tetap, para fuqahâ' mengatakan bahwa hukuman adalah wajib dan tetap tanpa kecuali, dan demikian, mereka tidak menyisakan ruang bagi penyesalan dan perubahan diri dalam pengadilan pidana hudûd. ${ }^{12}$

Pernyataan Kamali mengisyaratkan terjadinya redefinisi konsep hudûd dalam Islam yang selama ini dibangun oleh para yuristik. Pada akhir analisisnya, ia menyuguhkan tesis bahwa konstruksi hudûd sebagai bentuk pidana yang final merupakan hasil ijtihad para ulama fiqh yang muncul belakangan dan bertentangan dengan pembacaan nash secara holistik.

Menguatkan gagasan Kamali, Fazlur Rahman juga memberikan tesis menarik bahwa dalam dua ayat (Q.S al-Baqarah [2]: 229-230), istilah hudûd muncul enam kali berkaitan dengan perceraian, menuntut laki-laki untuk mempertahankan ataupun melepaskan

12Muhammad Hashim Kamali, Membumikan Syariah; Pergulatan Mengaktualkan Islam, terj. Miki Salman “Shariah Law; an Introduction” (Bandung: Mizan, 2013), 256-257. 
isteri mereka secara $b i$ al-ma'rûf, yaitu sesuai dengan adat kebiasaan yang baik. Selanjutnya Rahman mengatakan:

Fakta ini harusnya mendorong kita untuk berhenti sejenak dan berpikir tentang betapa kecilnya perhatian al-Qur'an terhadap aspek murni hukum dan betapa besar dan utama al-Qur'an menekankan pada sisi nilai moral suatu komunitas. Aspek hukum tentu harus menerapkan keadilan dan perangkat hukum yang memadai harus dikembangkan. Namun komunitas dibiarkan untuk membentuk hukum tersebut dengan panduan dan semangat moral al-Qur'an yang menunjukkan hanya sedikit kecenderungan untuk menetapkan hukum yang keras dan tetap. Mereka yang mengklaim telah mengambil hukum Alläh ke dalam tangannya sendiri dan berusaha untuk menerapkannya secara literal telah melakukan dua kesalahan sekaligus. ${ }^{13}$

Untuk menguatkan pandangan Kamali dan Rahman, terkait diskursus hudîd dalam Al-Qur'an, penulis menukil catatan alAshfahânî yang mengemukakan bahwa terma al-hadd ( $\underline{h} u d \hat{u} d)$ dalam pengertian umum adalah pemisah antara dua sesuatu yang menyebabkan keduanya tidak saling bercampur.14 Ibnu Manzhur dalam Lisân al-`Arab juga memaknai terma $\underline{h} u d \hat{u} d$ merupakan bentuk plural dari kata hadd. Kata hadd secara etimologis berarti sesuatu yang memisahkan antara dua benda atau dua hal yang menghalangi pencampuran antara keduanya. ${ }^{15}$

Hakikat hudûd dalam al-Qur'an lebih menekankan pada ketentuan-ketentuan agama baik berupa larangan (perintah untuk ditinggalkan) dan telah ditetapkan batasan hukumnya oleh Allāh. Semua bentuk $\underline{h} u d \hat{u} d$ Allāh tersebut meliputi empat kategori, yaitu: (1) aturan yang ketentuannya tidak boleh ditambah atau dikurangi seperti jumlah rakaat dalam shalat wajib; (2) aturan yang boleh

13Fazlur Rahman, "The concept of hadd in Islamic law." dalam Islamic Studies Journal, edisi 4:237-52., 1965), 240. Sebagaimana dikutip oleh Ziba Mir Hosseini, Memidanakan Seksualitas; Hukum Zina sebagai Kekerasan terhadap Perempuan dalam Konteks Islam, (Jakarta: INSIST dalam Kampanye anti-Kekerasan perempuan, 2010), 24-25

14 Al-Râghib al-Ashfahânî, Mufradât Alfâzh al-Qur'ân, (Damaskus: Dar al-Qalam, 1412 H./1992 H), 221.

${ }^{15}$ Abû Fadl Jamal al-Dîn Muhammad ibn Mukram ibn Manzhûr al-Ifriqî al-Mishrî, Lisân al- 'Arab (Beirut: Dar al-Kutub al-'Ilmiyyah, 1992), 140. Lihat juga dalam karya Mûsa Ibn Muhammad Ibn al-Milyânî al-Ahmadî, Mu'jam al-Af'âl al-Muta'addiyah biHarfin, (Jeddah: Dar al-Nasyir, 2009), 47 yang memaknai hadd dengan batas pemisah di antara dua perkara. 
ditambah ketentuannya dan tidak boleh dikurangi, misalnya kadar zakat; (3) Aturan yang boleh dikurangi tetapi tidak boleh ditambah, misalnya masalah poligami tidak boleh lebih dari empat isteri; (4) Aturan yang ketentuannya boleh ditambah atau boleh dikurangi, misalnya jumlah rakaat shalat sunnah dluhâ. ${ }^{16}$

Yang menarik adalah ketika Al-Qur'an membicarakan hudûd dengan berbagai bentuknya dan redaksinya selalu melekatkan dirinya dengan lafazh Allāh ( $\underline{h} u d \hat{u} d$ Allāh). Dari sini kemudian para ulama fiqh memaknai bahwa Allāh (inklusif Rasul-Nya) sajalah yang berhak membuat $\underline{h} u d \hat{u} d$ tersebut. Walhasil $\underline{h} u d \hat{u} d$ dalam pandangan ulama fiqh merupakan hak Allāh; hudûud berarti "pemberian hukuman dalam rangka hak Allāh."17

Perangkat dan konstruksi haqq Allāh yang melekat dalam ayatayat $\underline{h} u d \hat{u} d$, tidak boleh dirubah-rubah bentuk-jenisnya. Al-Qur'an tidak membuat garis demarkasi antara hak Allāh dan hak manusia dalam $\underline{h} u d \hat{u} d .{ }^{18}$ Pembagian demikian telah menyisakan problem serius dalam diskursus hudûd yang telah berdampak pada kesimpulan seorang mujtahid dan manusia tidak berhak merubah jenis-jenis

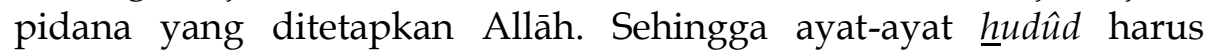
diterima dan diterapkan dalam segala kondisi apapun dan di ruang manapun. Sementara itu, klausul penyesalan (taubah) dan perbaikan (detterence) yang menjadi bagian integral dalam ayat-ayat yang diklaim para fuqaha' sebagai ayat hud̂̂d justru diabaikan bahkan nyaris hilang dari sorotan kajian mereka. Walhasil yang mencuat ke permukaan adalah kontsruksi hudûd yang parsial dan tidak menyentuh persoalan-persoalan riil.

\section{Diskursus $\underline{h} u d \hat{u} d$ dalam Hadits}

Para teoritisi hukum Islam mengajukan argumen bahwa para fuqaha' dalam merumuskan kontruksi hhudûd yang identik dengan al'uqūbatal-muqaddarah tampaknya lebih berbasis pada penggunaan Sunnah dan tradisi yang sudah ada. Pada titik ini menarik mencermati tesis Abdullahi Ahmed An-Na'im:

16Ibid., 221-222.

17al-Sayyid Sabiq, Figh al-Sunnah, Jilid II, (Mesir: Maktabah wa Mathba'ah, 1974 M), 14.

${ }^{18}$ Muhammad Hashim Kamali, Punishment; an Analysis of Hadd in the Quran (Kualalumpur: tr. Publisher, 2004), 135-6. 
Bahkan ketika diambil dari Al-Qur'an pun, hudîd memunculkan problem yang serius. Karena Al-Qur'an merupakan teks keagamaan, maka ia memberi tuntunan yang sedikit saja dalam ayat-ayat yang relevan mengenai definisi yang sah dan unsur-unsur spesifik masing-masing hadd tersebut. Para ahli hukum perintis, menyusun pemahaman mereka sendiri tentang hudûd melalui penggunaan Sunnah dan tradisi yang sudah ada. Karena masalah tersebut bisa dijadikan salah satu pertimbangan hukum tentang otensitas dan penafsiran tradisi yang relevan. ${ }^{19}$

Tesis An-Na'im diperkuat dengan data beberapa teks-teks keagamaan yang terbingkai dalam Sunnah yang mengidentikkan hudîd dengan bentuk-bentuk pidana yang digariskan oleh Al-Qur'an. Di antaranya hadits Nabi yang berbunyi:

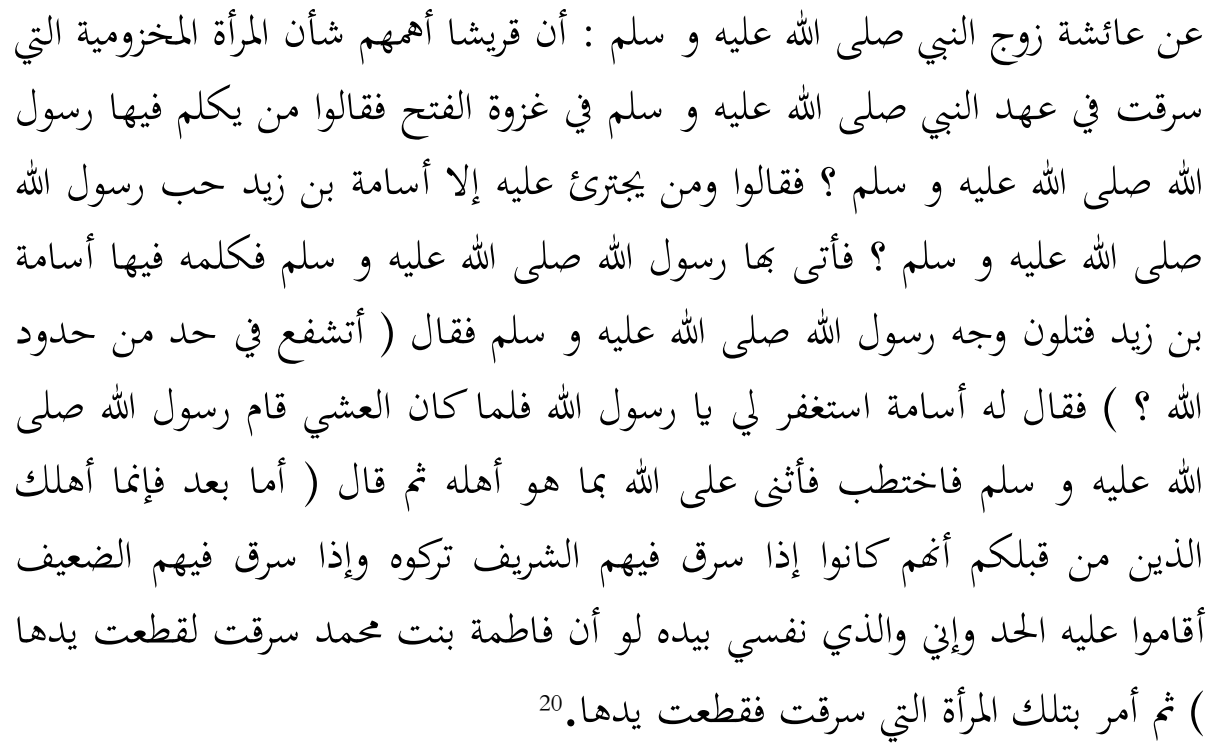

Dari 'Aisyah r.a. dia berkata: "Sesungguhnya salah satu pembesar wanita dari suku Quraisy dari Bani Makhzumiyah telah melakukan pencurian. Mereka berkata: "Siapa yang akan menyampaikan hal ini kepada Rasulullah SAW? Secara serentak

${ }^{19}$ Abdullahi Ahmed An-Na'im, Dekonstruksi Syari'ah; Wacana Kebebasan Sipil, HAM dan Hubungan Internasional dalam Islam Terj. Ahmad Suaedy dan Amirudin ar-Rany "Toward an Islamic Reformastion: Civil Liberties, Human Right and Internastional Law" (Yogyakarta: LKiS Group, 2011), 179.

${ }^{20}$ Muslim Ibn al-Hajjaj Abu al-Husain al-Qusyairi, Shahih $\underline{h}$ Muslim, tahqiq oleh Muhammad Fu'ad 'Abd al-Baqi, Juz III (Beirut: Dar Ihya' al-Turats al-'Arabi, t.th.), 1311 
mereka menjawab: "Kami rasa hanya Usamah saja yang berani menyampaikannya, karena dia adalah kekasih Rasulullah". Maka Usamah pergi memberitahukan kepada Rasulullah. Kemudian Rasulullah bersabda: "Apakah maksud kamu semua untuk meminta syafaat atas salah satu hukum Allah?' Lalu Rasulullah berkhutbah, 'Wahai manusia! Sesungguhnya yang menyebabkan binasanya ummat-ummat sebelum kamu adalah apabila terdapat seorang pembesar mencuri namun dibiarkan (tanpa dihadd), sebaliknya, jika terdapat orang yang lemah telah mencuri, mereka akan menjatuhkan hukuman atasnya. Demi Allah, sekiranya Fatimah binti Muhammad mencuri, maka pasti akan saya potong tangannya". (HR. Muslim)

Terdapat kata kunci dalam hadits: law anna fâthimah bint Muhammad saraqat laqatha'tu yadaha (sekiranya Fatimah binti Muhammad mencuri, niscaya saya (Nabi) yang memotong tangannya). Statemen ini mengindikasikan bahwa hukum pidana Islam tidak tebang pilih dalam eksekusinya. Pada kasus yang terdapat hadits ini dikisahkan bahwa ada seorang wanita dari Bani Makhzum telah meminjam perhiasan dari orang lain namun mengingkarinya. Kemudian wanita itu meminjam perhiasan lagi dan mengingkarinya lagi. Akan tetapi, pengingkaran tersebut diketahui orang banyak dan mereka berkehendak untuk mengajukan kasus ini kepada Rasulullah. Ketika kasus ini sampai ke tangan Rasulullah, beliau menetapkan pidana potong tangan.

Penetapan pidana potong tangan ini membuat mereka ragu dan bingung untuk melaksanakan sanksi pidana tersebut sebab wanita yang harus dipotong tangannya itu adalah wanita yang terhormat. Kemudian mereka bermusyawarah untuk menentukan orang yang dapat menjembatani yang akan menghadap Rasulullah untuk memintakan pembebasan pemidanaan bagi wanita tersebut. Maka mereka sepakat menunjuk Usamah bin Zaid, putra angkat Rasulullah, yang akan memintakan pembebasan hukuman tersebut. Ketika Zaid mengajukan permohonan pembebasan hukuman, Nabi pun marah dan berkata kepada Zaid sebagaimana tertera dalam potongan hadits di atas. ${ }^{21}$

Kata kunci lainnya dari hadits ini yang menekan bahwa $\underline{h} u d \hat{u} d$ berkaitan dengan dan identik dengan 'uqûbah atau potong tangan adalah kata أتثفع فى حد من حدود الله: Kemudian, beliau bangun dan

21Lihat dalam al-Hafidz Ibn Hajar Al-`Asqalani, Bulugul Maram Min Adillatil Ahkam, (Beirut: Darul Fikr, 1998), 217. Lihat juga dalam karya al-Shan'ani, Subulus Salam..., Juz IV,42. 
berpidato di hadapan orang banyak seraya menjelaskan bahayanya permohonan pembebasan seperti yang dilakukan Usamah bin Zaid tersebut. Permohonan tersebut akan membuat aturan-aturan Allāh tidak berlaku. Rasulullah juga menambahkan penjelasannya bahwa penyebab kehancuran umat-umat terdahulu pun, adalah karena mereka menerapkan aturan-aturan Allāh dan sanksinya kepada orang-orang yang lemah dan fakir saja. Kenyataan ini membuat Allāh marah dan hukuman-Nya pun menimpa mereka.

Hadits lain yang membicarakan hudûd adalah hadits yang diriwayatkan Imam Muslim yang berbunyi:

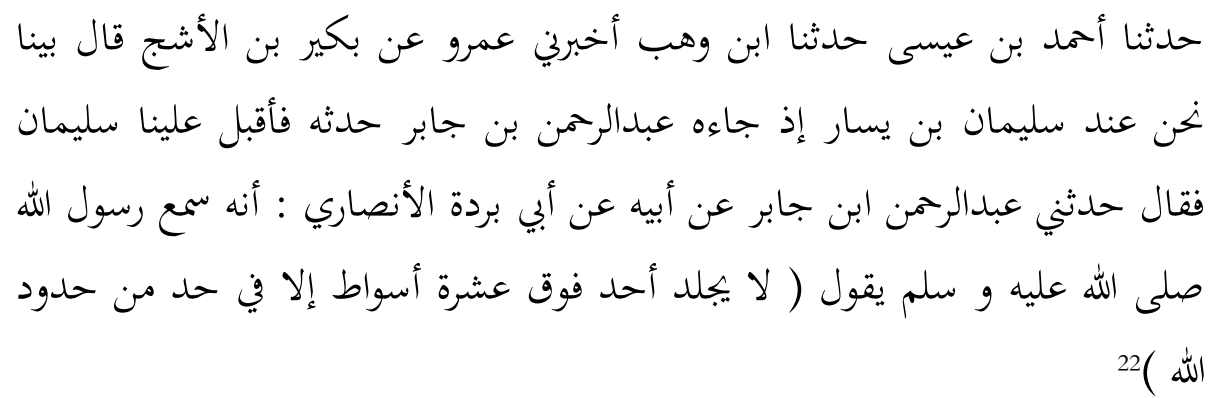

Telah menceritakan kepada kita Ahmad Ibn Isa, telah menceritakan kepada Ibn Wahab, telah memberitahukan saya 'Amru, dari Bukair ibn al-Asyaj berkata, di antara kami dan di sisi Sulaiman ibn Yassar karena telah mendatanginya 'Abd-alRahman Ibn Jabir telah menceritakan kepadanya kemudian menghadap le arah kita Sulaiman seraya berkata: telah menceritakan kepada saya 'Abdurrahman Ibn Jabir dari Ayah-nya dari Abu Burdah al-Anshari: bahwasannya ia mendengar Rasulullah SAW bersabda: "tidaklah seseorang dihukum jilid (dera) di atas sepuluh kali deraan kecuali dalam hukuman dalam hadd dari hudûd Allāh.

Kata kunci yang membicarakan bahwa $\underline{h} u d \hat{u} d$ identik dengan bentuk pidana dari hadits di atas adalah kata jild dan $\underline{h} u d \hat{u} d$ yang keduanya digunakan secara bersamaan dan saling berkaitan. Dengan kata lain -secara pendekatan mafhūm manthūq-- bentuk-bentuk pidana

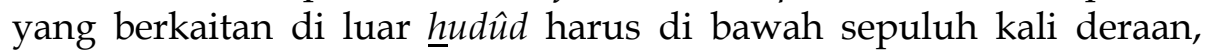
dan, apabila melebihinya, maka pidana dera tersebut masuk dalam kategori aspek pidana $\underline{h} u d \hat{u} d$. Berkaitan dengan hadits ini al Bassam menjelaskan:

Para ulama berbeda pandangan terkait makna ungkapan "illa fi haddin min hududillah" sebagian ulama berpandangan bahwa yang dimaksud dengan

22Ibid., Juz III, 1322. 
Junaidi Abdillah

hudûd adalah 'uqūbat (hukuman-hukuman) yang kadarnya telah terukur secara syara' seperti hukuman zina, qadzaf dan sariqah, qishash atas jiwa dan selain itu berupa pencederaan. Atas dasar inilah, maka selain hukumanhukuman di atas, termasuk katagori maksiat yang hukuman bagi pelakunya masuk dalam ranah ta'zir , yaitu maksimal sepuluh kali deraan dan bisa kurang. Pandangan ini adalah pandangan paling umum dari madzhab Imam Ahmad kendati ada pandangan sebagian golongan yang menginginkan hukuman secara pasti bagi pelaku maksiat. ${ }^{23}$

Selain hadits hadits Muslim di atas, terdapat hadits lain yang membicarakan $\underline{h} u d \hat{u} d$ identik dengan hukuman. Adalah hadits yang diriwayatkan oleh Abu Dawud yang berbunyi:

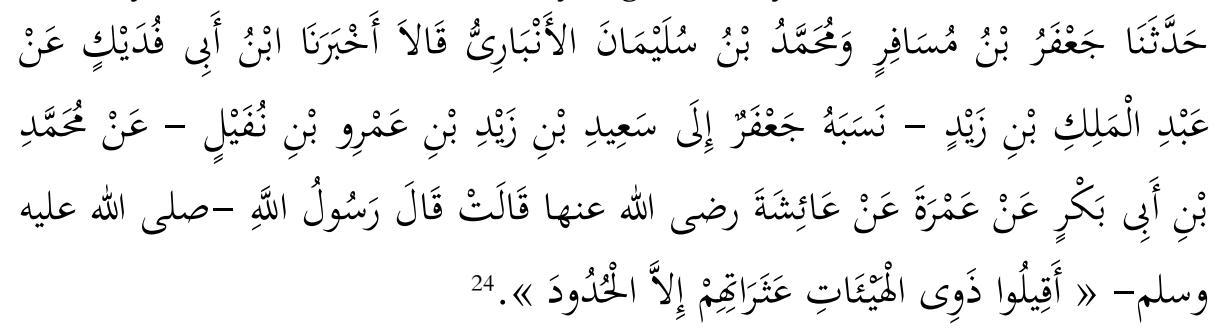

Telah menceritakan kepada kita Ja'far Ibn Musafir dan Muhammad Ibn Sulaiman al-Anbari keduanya berkata, telah memberitahukan kepada kami Ibnu Abi Fudaik, dari 'Abd al-Malik Ibn Zaid --yang nasabnya adalah Ja'far sampai pada Sa'id Ibn Zaid Ibn 'Amr Ibn Nufail-- dari Muhammad Ibn Abu Bakar dari 'Amrah dari 'Aisyah berkata, bersabda Rasulullah: "maafkanlah kekeliruan (tergelincirnya) orang-orang yang baik, kecuali dalam perkara hukuman hadd. (HR. Abu Dawud)

Dilihat dari bentuk matannya, hadits ini merupakan perintah kepada para hakim (ulî al-amr) untuk memberikan keringanan bahkan pengampunan bagi orang yang berdosa. Namun demikian, peringanan penjatuhan pidana atau pengampunan tidak diperkenankan dalam pidana $\underline{h} u d \hat{u} d$. Abu al-Thayyib mengemukakan penjelasan tentang hadits tersebut:

Maksudnya kecuali dalam perkara yang diwajibkan dalam aspek hudûd. Sedangkan kalimat idra'ū di sini khithāb-nya (ditujukan) untuk para pemimpin atau lembaga yang berkompeten untuk melakukan hukuman dan pembinaan. Sementara yang dimaksud dengan al-'atsarät memang

${ }^{23}$ Al-Bassam, Taysîr `ala Allāh min Syarh 'Umdah al-A $\underline{h k a ̂ m, ~ J u z ~ I I, ~(B e i r u t: ~ M a t h b a ' a h ~ l i ~}$ Nasyr wa al-Dakwah, t.th), 164.

${ }^{24}$ Abû Dawûd Sulayman Ibn al-Asy'ats al-Sajastânî, Sunan Abû Dawûd, Juz IV, (Beirut: Dar al-Kitab al-'Arabi, t.th.), 232. 
diarahkan pada persoalan-persoalan aspek ta'zīr untuk meniadakan hak dari hak-hak Allāh yang terkandung dalam hudûd. ${ }^{25}$

Sepenggal penjelasan Abu Thayyib menjelaskan bahwa terma hudûd dalam konteks hadits ini identik dengan 'uqûbah. Perintah pengurangan bahkan pemaafan ditujukan kepada para pemimpin (hakim) yang berhak menjatuhkan sanksi dan pembinaan bagi manusia pelaku kejahatan. Adapun yang dimaksud dengan al-atsarât dalam hadits ini menunjukkan perintah pada wilayah $t a^{\prime} z \hat{\imath} r$ untuk meniadakan atau menghilangkan hak-hak Allāh. Terkait hadits ini terkait dengan makna hulûud identik dengan jarîmah adalah penjelasan 'Abd al-Ra' ûf al-Manawî yang mengatakan:

Ringankanlah hukuman bagi orang yang mempunyai problem hukum kecuali dalam bidang hudud. Maka jika terdapat ampunan dari korban, dapat menggugurkan jarimah jika telah jelas. ${ }^{26}$

Bahwasanya hadits tentang minimalisasi hukuman kecuali dalam hud $u$ d bila melalui berbagai kajian dan pertimbangan. Terdapat hadits lain yang secara gamblang membicarakan h hudûd yang dilekatkan dengan kajian tindak pidana (jarîmah) dan hukuman ("uqûbat) sebagaimana diriwayatkan oleh al-Tirmidzi:

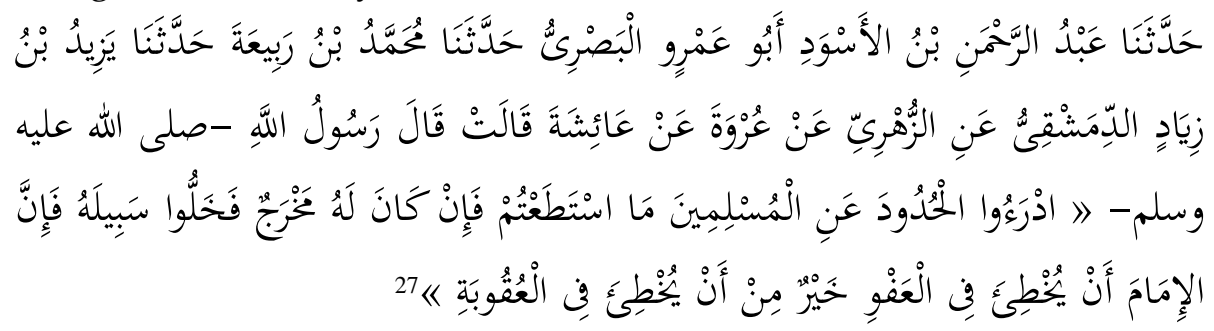

Telah menceritakan kepada kami Abdurrahman Ibn al-Aswad Abu 'Amrin alBashri, telah menceritakan kepada kami Muhammd Ibn Rabi'ah, telah menceritakan kepada kami Yazid Ibn Ziyad al-Damasyqi dari al-Zuhri dari 'Urwah dari 'Aisyah

${ }^{25}$ Abû Thayyib Muhammad Syams al-Haqq al-'Azhîm Âbâdî, 'Awn al-Ma'bûd Syarh Sunan Abû Dâwûd, Juz IX, Tahqiq 'Abd al-Rahman Muhammad 'Utsman (Madinah Munawwarah: Maktabah al-Salafiyyah, 1968 M/1388 H), 1507.

${ }^{26}$ Abd al-Ra' ûf al-Manâwî, Faydl al-Qadîr Syarh al-Jâmi' al-Shaghîr, Juz II, (Mesir: Makatabah al-Tijariyyah al-Kubra, 1356 H), 294.

27Muhammad Ibn 'Isâ Abû 'Isâ al-Tirmidzî al-Silmî, al-Jâmi' al-Shahîh Sunan alTurmudzî, Juz IV, ditahqiq oleh Ahmad Muhammad Syakir dkk (Beirut: Dar Ihya alTurats al-'Arabi, t.th.), 33. 
berkata, telah bersabda Nabi SAW: "Tinggalkanlah 'hudûd atas muslimin semampu kamu apabila telah ditemukan sebuah solusi, maka tinggalkanlah 'hudûd tersebut, sebab seorang pemimpin yang salah dalam pengampunan lebih baik dari pada ia salah dalam menjatuhkan hukuman". (HR. al-Tirmidzi)

Untuk menangkap pesan inti atau maksud utama hadits ini maka perlu dikaitkan terlebih dahulu kaitannya hadits ini dengan hadits lain. Hadits ini berkorelasi kuat dengan hadits yang berbunyi:

"hindarilah penjatuhan pidana hrudûd jika terdapat keasamaran.

Penjatuhan sebuah sanksi pidana yang terkandung dalam $\underline{h} u d \hat{u} d$ akan terlaksana jika syarat-syarat yang terkandung dalam jarîmah telah terpenuhi. Seperti kesaksian empat orang saksi yang adil dalam perbuatan zina, kadar nishâb tertentu dari barang yang dicuri yang mensyaratkan pemotongan tangan dan syarat-syarat lainnya. Namun jika syarat-syarat dan ketentuan tidak terpenuhi maka bentuk pidana yang diancamkan harus dicarikan solusi atau alternatif lain. Hal ini dimaksudkan menghindari kesalahan dalam penjatuhan hukuman yang dihasilkan dari pengamatan yang salah. Sehingga, pemberian maaf dari hakim --kendati di dalamnya terdapat-- kesalahan itu lebih baik dan mulia ketimbang penjatuhan pidana yang salah.

Hal ini dapat dicontohkan oleh ijtihad Umar yang tidak memotong tangan seorang pencuri di masa paceklik. Nabi juga tidak menghukum orang yang mengaku berzina sebelum terbukti kesalahannya. Dan masih banyak contoh perbuatan yang menggambarkan akan keluwesan hukum Islam. Hal ini sesuai dengan kaidah yang berbunyi:

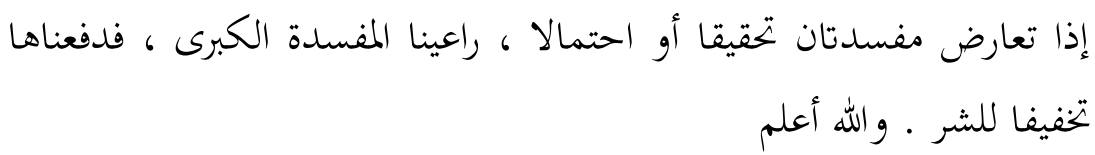

Apabila terdapat dua kerusakan yang saling bertentangan baik secara nyata maupun sebatas dugaan, maka bahaya yang lebih besar dicermati dengan seksama untuk kemdian harus ditinggalkan demi bahaya yang lebih ringan". 28

28'Abd al-Rahmân Ibn Nâshir al-Sa'dî, Bahjah al-Qulûb al-Abrâr wa Qurrah 'Uyûn alAkhyâr fî Syarh Jawâmi' al-Akhbâr, Juz I, (Saudi Arabia: Kementerian Wakaf dan Dakwah, 1423 H), 188. 
Hadits di atas diawali dengan kata $i d r a^{\prime} \hat{u}$ yang merupakan fi'il amr yang mukhäthab-nya adalah para pemimpin, hakim, dan yang merepresentasikan keduanya. Sesuai kaidah ushüliyyah yang berbunyi: al-ashl fi al-amr li al-wujûb (hukum asal dari perintah adalah wajib). Dengan demikian hadits ini mengandung kewajiban bagi hakim dan para pemimpin agar menumbuhkan kehatian-hatian dalam menjatuhkan pidana yang terkandung dalam pidana $\underline{h} u d \hat{u} d$.

Berangkat dari pemahaman hadits tersebut, para fuqahâ' sepakat bahwa seseorang hanya dapat dijatuhi pidana ( $\underline{h} u d \hat{u} d)$ kalau perbuatan pidana yang dituduhkan kepadanya betul-betul sudah memenuhi syarat, terbukti, dan deliknya telah sempurna. Untuk syarat-syarat pencurian misalnya, hukum Islam menentukan: harta berharga, mencapai nishâb, tidak ada unsur syubhâh milkah, dan disimpan dalam tempat penyimpanan. Sebagian ulama menambahkan syaratnya adalah pelaku kambuhan dan bukan untuk memenuhi kebutuhan primer. Hal inilah yang dipertimbangkan Umar ketika tidak menjatuhkan pidana potong tangan bagi seorang pencuri. Bukan karena ia tidak melaksanakan teks, justru Umar mengamalkan perintah Al-Qur'an dengan menjaga kesempurnaan syarat dan rukun sebuah delik pidana.

Kata kunci yang dipakai dalam memahami hadits ini adalah kata hudûd pada awal matan hadits dan kata al-'uqûbah pada akhir matan hadits tersebut. Berdasarkan pendekatan kedua kata kunci di atas, dapat dipahami bahwa maksud utama hudîf dalam hadits di atas adalah 'uqūbah. Sepanjang penelusuran lebih jauh dalam alSunnah, dengan menggunakan kata kunci "hudd̂ud" dalam sumbersumber utama hadits, semua diskursus dan penggunaan terma hudûd dalam al-Sunnah mengarah pada pemahaman pemberian sanksi "hukuman" bagi para pelaku kejahatan dengan bentuk pidana yang telah ditentukan oleh syara'.

Tradisi al-Sunnah menggunakan terma hudûd lebih sempit dan spesifikasi dengan kajian-kajian pidana dan pemidanaan saja. Hal ini diperkuat dengan hadits Nabi yang berbunyi:

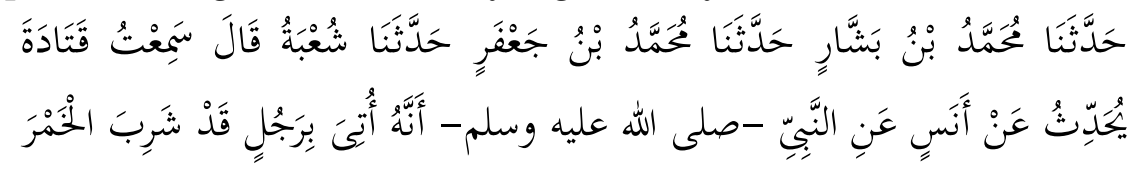




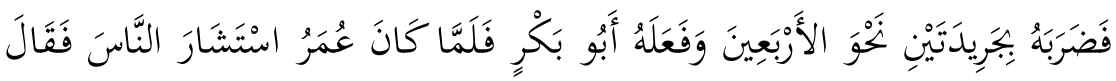

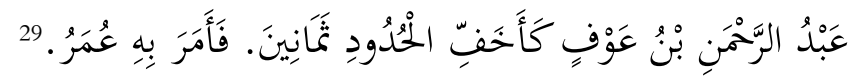

$$
\begin{aligned}
& \text { “...Saya telah mendengar Qatadah berkata dari Anas bin Malik }
\end{aligned}
$$

Hadits di atas secara tekstual menyatakan adanya korelasi kuat antara $\underline{h u d \hat{u} d}$ dan bentuk pidana. Redaksi kunci fadlarabahu bi jarîdatayn (memukulnya dengan dua pelapah kurma) sebanyak empat puluh kali dan dikaitkan langsung pada akhir matan hadits dengan

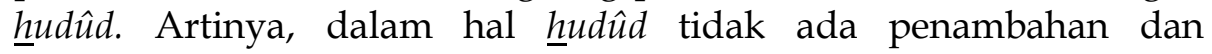
pengurangan putusan pidana. Hadits ini mengarahkan pada kesimpulan bahwa diskursus dan terminologi h $\underline{u} u \hat{u} d$ dalam al-Sunnah banyak diwarnai dengan bentuk-bentuk pidana yang telah ditentukan kadar dan jumlahnya (al-'uqûbât al-muqaddarât).

\section{Konstruksi $\underline{h} u d \hat{u} d$ menurut Yuristik Muslim}

Pelacakan terhadap konstruksi $\underline{h} u d \hat{u} d$ dalam fiqh dapat tergambarkan dari paparan al-Syawkanî dalam Nayl al-Authâr:

Hadd secara bahasa adalah mencegah, darinya kemudian dinamanakan pintu-pintu sebagai pembatas, maka dinamakanlah hukuman-hukuman kejahatan sebagai batas-batas. Sebab, hukuman tersebut dapat mencegah (menghalangi) pelaku kejahatan dari terulanginya kembali kejahatan tersebut yang telah dibatasi sebagai tujuan umumnya. Sedangkan secara istilah yang disebut hadd adalah hukuman-hukuman yang telah ditentukan kadarnya karena adanya hak Alläh, maka tidak termasuk hadd kejahatan dalam katagori ta'zìr sebab tiadanya ukurannnya dan qiashas, karena keduanya adalah hak Adam". ${ }^{30}$

${ }^{29}$ Abû 'Isâ al-Tirmidzî, Sunan al-Tirmidzî̀, Juz IV, (Beirur: Dar al-Kutub al-'Arabiyyah, t.th.,), 16. Lihat juga Lihat dalam Muhammad bin Ismail al-Kahlani al-Shan'ani, Subul al-Salam, Jilid IV, (Bandung : Dahlan, t.th,), 28.

${ }^{30}$ Muhammad Ibn 'Ali Ibn Muhammad al-Syawkânî, Nayl al-Authâr min Ahââits Sayyid al-Akhyâr Syarh Muntaqâa al-Akhbâr, Juz VII, (Damaskus: Idarah al-Thiba'ah alMuniriyyah,1966), 146. 
Rumusan $\underline{h} u d \hat{u} d$ di atas tidak jauh berbeda dengan proposisi dan analisis yang dikemukakan Taqî al-Dîn Abû Bakr dalam karyanya Kifâyah al-Akhyâr yang menyatakan:

"Hudûd merupakan bentuk plural dari hadd yang dalam bahasa Arab berarti "mencegah". Dari sini dapat disebut bahwa batas dinding merupakan pencegah masuknya orang lain, karenanya pintu-pintu sebagai dinding pemisah agar mencegah orang yang masuk maupub keluar, dinamakan hudûd karena ia merupakan batas-batas untuk mencegah manusia melakukan perbuatan-perbuatan jahat, dengan demikian maka Alläh membatasinya dan menentukan kadarnya agar tidak ditambahi maupun dikurangi kadarnya, bentuk hudûd sendiri pada era awal Islam masih berupa denda-denda uang yang kemudian dihapus oleh bentuk-bentuk hrudîd ini. 31

Kedua proposisi dari al-Syawkânî dan Taqî al-Dûn di atas menunjukkan konstruksi $\underline{h} u d \hat{u} d$ dalam fiqh Islam yang identik dengan hukuman-hukuman badaniah yang bersifat pasti. Bahkan ulama Hanabilah bernama Syaraf al-Dîn al-Hajâwî ketika mengkaji bab hudûd selalu mengidentikan dengan hukuman pasti yang wajib dilaksanakan. Lebih detail ia mengemukakan pandangan tentang

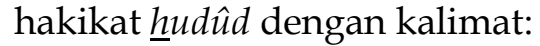

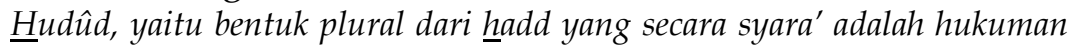
yang kadarnya ditentukan sebagai upaya pencegahan terjadinya tindak pidana yang sama, di mana hukuman tersebut wajib dieksekusi kendati yang menjalankan adalah bersekutu atas pelakunya dalam hal pelanggaran sebagai bentuk pertolongan bagi pelakunya. Demikian halnya dengan hal amar ma'ruf nahi munkar, maka tidak boleh dikumpulkan antara dua pelanggaran. Dan hadd tidak wajib dieksekusi kecuali bagi mukallaf yang cakap dan mengetahui hal-hal yang diharamkan. ${ }^{32}$

Lagi-lagi kutipan di atas telah mengidentikan hudûd dengan hukuman-hukuman badan yang bersifat wajib. Menariknya, gagasan al-Hajâwî lebih menekankan upaya penegakkan hudûd sebagai bentuk pertolongan agar tidak mengulangi perbuatannya. Senada

31Taqî al-Dîn Abû Bakr Ibn Muhammad al-Husaynî al-Hashna al-Dimasqî al-Syâfi'î, Kifâyah al-Akhyâr fî Hill Ghâyah al-Ikhtishâr, Juz II, (Beirut: Dar Kutub al-'Ilmiyyah, t.th.), 178.

32Syaraf al-Dîn Mûsâ Ibn Ahmad Ibn Mûsâ al-Hajâwî, al-Iqnâ' fî Fiqh al-Imâm Ahmad Ibn Hanbal, Juz IV, Tahqiq 'Ābd al-Lathif Muhammad Musa al-Subki, (Libanon Beirut: Dar al-Ma'rifah, t.th), 244. 


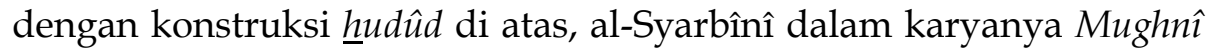
al-Muhtâj mengajukan statemen terkait definisi $\underline{h} u d \hat{u} d$, dengan ungkapan:

Makna hadd secara syara' adalah hukuman yang kadarnya telah ditentukan dan wajib dieksekusi sebagai hak Alläh sebagaimana dalam zina, dan hak Adam sebagaimana dalam hadd qadzaf. Dinamakan al-ȟhudûd sebagai batas-batas karena Allāh membatasi dan menentukan kadarnya, maka tidal diperkenankan bagi seorang pun untuk melampauinya. 33

Ungkapan al-Syarbînî menekankan bahwa hudûd lebih pada hukuman wajib dan melakukan dikotomisasi dalam pemidanaan antara hak Allāh yang termanifestasi dalam h hud̂̂d dan hak Adam yang terangkum dalam hukuman-hukuman di luar hudûd. Kutipan berikutnya dari gagasan 'Abd al-Qâdir 'Awdah yang mengajukan pendefinisan $\underline{h u d \hat{u} d}$ dengan kalimat:

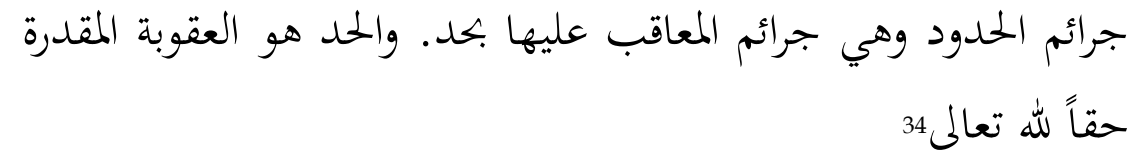

Tindak pidana al-hudûd yaitu tindak-tindak pidana yang dibalas dengan hukuman-hukuman yang bersifat hadd. Sedangkan hadd adalah hukuman yang kadarnya telah ditentukan sebagai hak Allāh.

Tidak jauh berbeda dengan rumusan $\underline{h} u d \hat{u} d$ di atas, Abu Syahbah mengemukakan istilah $\underline{h} u d \hat{u} d$ dengan kalimat:

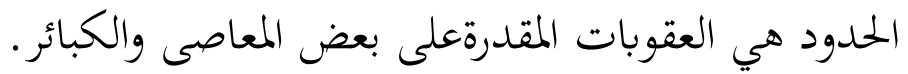

$\underline{H} u d \hat{u} d$ adalah hukuman-hukuman yang ukurannya telah tetap untuk sebagian tindak ma'siat atau dosa-dosa besar. ${ }^{35}$

Sedangkan ta'rif (definisi) hudîd dalam pandangan Abu Zahrah salah seorang ulama yang hidup pada era modern mengatakan bahwa yang dimaksud dengan $\underline{h u d \hat{u} d}$ adalah:

${ }^{33}$ Muhammad Khathib al-Syarbini, Mughni al-Muhtāj ilā Ma'rifati Ma'āni al-Alfāzl alMinhāj, Juz IV, (Beirut: Dar al-Fikr, t.th.), 155.

34'Abd al-Qadir 'Audah, al-Tasyri al-Jina'i Muqaranan bi al-Qanun al-Wadl'ī, Juz I, (Beirut: Dar al-Risalah al-Mu'assasah, 1996), 88.

${ }^{35}$ Muhammad Ibn Muhammad Abu Syahbah, al- $\underline{H} u d \bar{u} d$ fi al-Islām wa Muqāranatuha bi al-Qawānin al-Wadl'iyyah (Kairo: t.p., 1973), 129. 


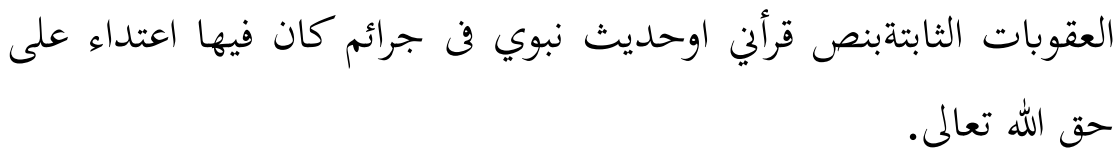

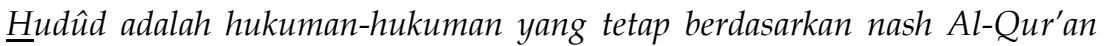
atau hadits Nabi terhadap perbuatan-perbuatan yang dilarang yang harus disegerakan atas hak Alläh. ${ }^{36}$

Berdasarkan dari kutipan proposisi-prosisi di atas, semakin memperjelas definisi dan hakikat $\underline{h} u d \hat{u} d$ dalam tradisi hukum Islam. Mendefinisikan hudûd sebagai 'uqübah muqaddarah merupakan mainstream yang banyak berkembang di kalangan fuqaha' merupakan hal yang tidak terbantahkan. Pertanyaannya, mengapa konstruksi yang mengidentikkan $\underline{h} u d \hat{u} d$ dengan hukuman lahir dan menjadi kesepakatan fuqaha'? Dalam hal ini, 'Audah memeberikan argumentasi lebih rinci:

Pada umumnya terma hadd merujuk pada tindakan-tindakan pidana kategori hudûd dan sanksi-sanksinya. Dengan demikian dapat dikatakan: "Pelaku kriminal hadd, maka sanksinya adalah hadd juga. Dan pada saat kata hadd merujuk pada bentuk kriminal, maka yang dimaksud adalah definisi kriminal beserta sanksinya. Artinya, bahwa hakikat hudûd adalah bentuk kriminal (pidana) yang mempunyai sanksi (hukuman) yang bentuknya telah ditetapkan syara'. Dengan demikian pendefinisian pidana hadd merupakan penamaan majazi. Dari sinilah sebagian fuqaha' berpendapat bahwa yang dimaksud dengan hadd adalah sanksi (hukuman) yang telah ditetapkan secara syara'. $^{37}$

Proposisi di atas telah mengantarkan argumentasi dan jawaban mengapa terma hadd identik dengan hukuman yang tetap. Dalam analisisnya, 'Awdah mengatakan bahwa secara tradisi kata hadd identik dengan jarimah hudûd yang di dalamnya juga mengandung ancaman-ancaman yang bersifat pasti pula. Sebagai ketentuan syara' yang bersifat final, maka tidak ada perubahan dalam jarimah hudûddengan berbagi sanksinya. Lebih lanjut 'Awdah mengatakan tentang karakteristik $\underline{h} u d \hat{u} d$ dibanding aspek hukum pidana lainnya. Ia menyatakan:

\footnotetext{
36Muhammad Abu Zahrah, al-Jarimah wa al-'uqübah fi Figh al-Islam (t.tp: Dar al-Fikr al'Arabi, 1973), 90.

37Ibid., Juz III, 375.
} 
Di dalam hudûd terdapat keistimewaan dan perbedaan yaitu: (1) bahwasanya hnudîd tidak boleh dikurangi atau ditambahi (2) bahwasannya di dalam hudûd tidak ada unsur pemaafan baik dari hakim atau pejabat negara yang berwenang ataupun dari pihak korban. Ketentuan kedua ini jika telah telah tertangkap dan diadili oleh yang berwenang, namun jika belum tertangkap maka terbuka dengan pemaafan dari pihak korban namun hanya untuk pidana-pidana tertentu; (3) bahwa dalam hudûd terdapat hak-hak Alläh SWT dan inilah ungkapan yang datang dari Islam dan yang dimaksudkan dengan hak umum dan bertujuan untuk mewujudkan kemaslahatan umum untuk publik. 38

Tiga karakteristik yang dimiliki dalam aspek $\underline{h} u d \hat{u} d$ yang diajukan 'Awdah telah meniscayakan ketetapan final dalam bentuk jarimah yang bernama $\underline{h} u d \hat{u} d$. Konstruksi demikian hingga kini masih menjadi pemahaman yang mengakar di kalangan fuqaha' dari klasik, skolastik hingga hingga era modern. Menurut Muthi' Allāh Dakhil Allāh Sulaiman dalam disertasinya yang berjudul al-'Uqūbāt alMuqaddarah wa Hikmatu Tasyri'ihā Fi Dla'ui al-Kitāb wa al-Sunnah menjelaskan bahwa para fuqaha' sepakat bahwa hudîd adalah bentuk hukuman yang telah ditetapkan oleh Syāri' dan wajib dilaksanakan sebagai hak Allāh (al-haddu syar'an 'uqūbah muqaddarah min al-Syāri' alhakim wajabat haqqān lillāhi Ta'āla 'alā man irtakaba mujībaha). ${ }^{39}$

Adapun cakupan jarimah al-hrudûd ada 17 jenis tindak pidana. Dari ketujuh belas tersebut ada enam jenis tindak pidana yang

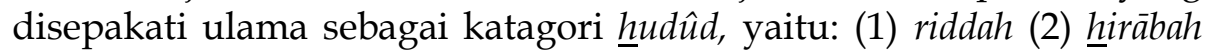
sebelum taubat dan ditangkap (3) zina (4) qadzaf (5) minum khamr baik mabuk atau tidak (6) pencurian (sariqah) Sedangkan jarimah bughāh masih diperdebatkan di kalangan para fuqaha'. ${ }^{40}$ Sedangkan tindak pidana (jarimah) yang masih diperdebatkan apakah ia termasuk hudûdatau tidak yaitu: (7) mengingkari pinjaman (hutang)(8) minum yang memabukkan selain dari khamr (9) qadzaf selain zina (10) mengingkari qadzaf (11) sodomi kendati dilakukan dengan istrinya (12) menyetubuhi binatang (13) hubungan sesama jenis (14) wanita yang berhubungan kelamin dengan kera atau

\footnotetext{
38Ibid.

${ }^{39}$ Muthi' ullah Dakhilullah Sulaiman al-Shurhaidi al-Luhaibi, al-'Uqubat al-Muqaddarah wa Hikmatu Tasyri'iha fi Dlaui al-Kitab wa al-Sunnah (Jeddah: Tihama,1983), 44-45.

40'Abd al-Wahhab Ibn Ahmad al-Anshari al-Sya'rani, Mizan al-Kubra, Jilid II, (Beirut: Dar al-Kutub al-illmiyyah, t.th.), 127.
} 
binatang lainnya (15) sihir (16) meninggalkan shalat karena malas dan (17) meninggalkan puasa ramadlan. ${ }^{41}$

Perbedaan-perbedaan konsepsi di atas terjadi karena tampaknya para fuqaha' fokus pada jenis perbuatan (jarimah) apa yang termasuk dalam kategori hudûd, apakah lebih dari enam perbuatan sebagaimana yang disebutkan di atas atau kurang dari enam, sebagai akibat dari pemahaman mereka yang berbeda-beda terhadap sumber tekstual ayat-ayat Al-Qur'an maupun Hadis tersebut. ${ }^{42}$

Konstruksi rumusan $\underline{h} u d \hat{u} d$ sebagai bentuk hukuman (pidana) yang berkadar pasti hukuman pasti juga disetujui oleh pakar lainnya yang terumuskan sebagai berikut:

Kata hudûd ini merupakan bentuk plural dari kata hadd yang secara bahasa berarti mencegah. Terma hudûd dalam kajian syari'at adalah hukuman yang berkadar pasti dan wajib diekseskusi sebagai hak Allah 'Azza wa Jalla. Dalam kitab Shihah juga dikatakan bahwa hadd adalah batas antara dua sesuatu. Batas sesuatu adalah pada ujungnya yang disebut muaranya. Sementara pada Kitab Maghrib disebut bahwa hakikat sesuatu harus ada batasnya, karena ia bersifat jāmī' dan māni'. Dari sini kemudian istilah haddād identik dengan pintu masuk untuk mencegah seseorang masuk. Bahwa hukuman bagi pelaku kejahatan adalah sebagai bentuk "hadd" karena ia dapat mencegah untuk mengulangi perbuatannya, juga dikatakan "hadd" karena ia kadarnya sudah ditentutkan. Tidakkah melihat bahwa dalam hukuman ta'zir tidak disebut sebagai "hadd" karena ia tidak ditentukan hukumannya. ${ }^{43}$

Diskursus 'uqūbah (pidana) selalu melekat dan atau tidak bisa dilepaskan dari bentuk-bentuk jarimah (kejahatan)-nya. Bahkan pada umumnya, yang dijadikan dasar kajian dan perdebatan lebih banyak diwarnai oleh bentuk-bentuk kejahatannya dibanding sanksi (ancaman atau hukumanya). Hal ini dapat dilihat dalam kitab fiqh semisal Fath al-Mu'inn, al-Lulu' wa al-Marjān, Bulügh al-Marām dan lain sebagainya. ${ }^{44}$

${ }^{41} I b n u$ Hajar al-'Asqalani, Fath al-Bari, Jilid XV, (Beirut: Dar al-Kutub al-illmiyyah, t.th.), 61 .

42Mohammed Said el-Awa, Punishment in Islamic Law, (Indianapolis: American TrustPublications, 1982), 2.

${ }^{43}$ Qasim Ibn Abdillah Ibn Amir 'Ali al-Qunuwi, Anis al-Fuqaha' fi Ta'rifat al-Alfazh alMutadawalah baina al-Fuqaha' (Jeddah: Dar al-Wafa', 1406), 173.

${ }^{44}$ Dalam masalah tindak pidana (criminal act), terdapat dua hal yang tidak dapat dipisahkan dan merupakan satu mata rantai yang tidak akan pernah terputus, yaitu 
Namun demikian, tidak jarang juga karya para fuqaha' yang selalu mengkaji hukum pidana Islam dari aspek pemidanaannya. Apabila ditelaah dan dikaji dari jenis sanksi atau hukuman (al'uqūbah)-nya, maka di dalam hud̂udterdapat tujuh jenis ancaman (hukuman) yang tercakup dalam katagori jarimah al-hhudîd, yaitu: (1) hukuman salib dalam QS. al-Maidah 5:33 untuk tindak pidana "muhāribah" atau "qath'u al-tharī"" (2) hukuman mati dalam QS. 5:33 (3) hukuman potong tangan dan kaki secara bertimbal balik dalam QS. 5:33 (4) hukuman buang dalam QS. 5:33 (5) hukuman penjara seumur hidup dalam QS. al-Nisa' 4:15 (6) Pidana potong tangan untuk pidana pencurian dalam QS. 5:38 dan (7) hukuman cambuk (dera) bagi tindak pidana perzinaan dan tuduhan palsu serta minum khamr (QS. 24: 2 dan 4).

Sedangkan bentuk lainnya terdapat dalam al-Sunnah seperti hukuman cambuk (dera) bagi peminum khamr. Selain itu juga ada hukuman lainnya yang didasarkan atas hadits Nabi adalah pidana rajam. Ketentuan hukuman rajam hanya terdapat dalam nash hadits yang keberadaannya diakui sebagai perinci dan penjelas Al-Qur'an. Diakui, hukuman rajam juga merupakan bentuk warisan tradisi masyarakat Arab pra-Islam sebagaimana hukuman yang terdapat dalam qishash (retaliation) dan diyat. ${ }^{45}$

\section{Analisis Kritis Konstruksi $\mathbf{H u d u ̂ d}$}

Berdasarkan kajian fiqh --berbasis pada pelacakan kitab-kitab fiqh-- makna dan hakikat $\underline{h} u d \hat{u} d$ identik dengan hukuman-hukuman yang bersifat pasti kadarnya. Ibarat dua sisi mata uang antara $\underline{h} u d \hat{u} d$ dengan 'uqübah adalah merupakan entitas yang tidak dapat dipisahkan. Kendati keduanya bisa dibedakan, namun kedua entitas dalam konstruksi para fuqaha' adalah dua bayi kembar yang saling sama. Sehingga kajian hukum pidana Islam sangat banyak diwarnai dengan bentu-bentuk hukumannya, dibanding jarīmah-jarīmah yang

kejahatan dan hukuman. Suatu bentuk perintah dan larangan saja tidaklah cukup untuk mendorong seseorang meninggalkan suatu perbuatan atau melaksanakannya, untuk itulah diperlukan sanksi berupa hukuman bagi siapa saja yang melanggarnya. Lihat dalam Abdul Salam, Figh Jinayat (Hukum Pidana Islam), (Yogyakarta: Ideal, 1990), 52.

${ }^{45}$ Robert Roberts, The Social Laws of The Qoran, Consideres and Compared With those of The Hebrew and Other Ancient Codes (New Delhi: Kitab Bhavan, 1977), 35-39. 
ada. Hal ini bisa dilacak dari karya besar 'Audah al-Tasyrī' al-Jinā' karya Muthi'ullah al-'Uqūbāt al-Muqaddarah, Karya Ahmad Fikri ‘Ukaz yang berjudul Falsafah al-'Uqübah fi al-Syarī'ah al-Islämiyyah merupakan karya-karya fuqaha' yang banyak mengkaji dari perspektif yang berbeda yaitu dari bentuk-bentuk hukuman (al-'uqūbah) dalam tradisi hukum pidana Islam. ${ }^{46}$

Dalam perspektif para fuqaha', pengertian hudtud masih terbelenggu sebagai ketentuan bentuk hukuman-hukuman yang final, tertutup dengan perubahan dan bersifat tauqifi konsekuensinya harus diterima apa adanya oleh setiap muslim. Terkait hal ini, penulis melihat para fuqaha' tampaknya lebih dipengaruhi oleh suatu pemahaman bahwa sumber-sumber tekstual sudah memberikan rumusan yang matang dan jelas tentang bentuk hukuman yang harus diberikan sehingga para fuqaha' cenderung untuk tidak lagi

46Hukuman dalam kajian hukum pidana Islam (figh jinayah) dikelompokkan dalam beberapa jenis, yaitu: Pertama, hukuman dilihat dari pertalian hukuman yang satu dengan yang lainnya. Dalam hal ini ada empat macam: (1) hukuman pokok, yaitu hukuman yang diterapkan secara definitif, artinya hakim hanya menerapkan sesuai apa yang telah ditentukan oleh nash. Dalam fiqh jinayah hukuman ini disebut

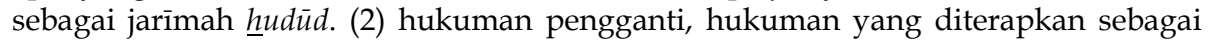
pengganti karena hukuman pokok tidak dapat diterapkan dengan alasan yang sah/benar. Misalnya qishash diganti dengan diyat, dan diyat diganti dengan dimaafkan (3) hukuman tambahan, yaitu hukuman yang menyertai hukuman pokoktanpa adanya keputusan hakim tersendiri. Misalnya bagi pelaku qadzaf diberlakukan hukuman berupa hilangnya hak persaksian dirinya, dan hilangnya hak pewarisan bagi pelaku pembunuhan. (4) Hukuman pelengkap, yaitu tambahan hukuman pokok dengan melalui keputusan hakim secara tersendiri. Misalnya selain dipotong tangannya bagi pelaku pencurian juga diberi tambahan hukuman dengan dikalungkannya tangan di lehernya. Kedua, hukuman dilihat dari kewenangan hakim dalam memutuskan perkara. Dalam hal ini ada dua macam: (1) Hukuman yang bersifat terbatas, yakni ketentuan pidana yang ditetapkan secara pasti oleh nash, atau dengan kata lain, tidak ada batas tertinggi dan terendah. Misalnya hukuman dera 100 kali bagi pelaku zina dan hukuman dera 80 kali bagi pelaku penuduh zina. (2) Hukuman yang memiliki alternatif untuk dipilih. Ketiga, hukuman dilihat dari obyeknya. Dalam hal ini ada tiga macam: (1) hukuman jasmani, seperti potong tangan, rajam dan lainnya (2) hukuman yang berkenaan dengan psikologis, ancaman dan teguran (3) Hukuman benda, ganti rugi, diyat dan penyitaan harta. Lihat dalam Makhrus Munajat, Hukum Pidana Islam di Indonesia (Yogyakarta: Bidang Akademik UIN Sunan Kalijaga, 2008), 116-117. Lihat juga Jazuli, Figh Jinayat: Upaya Menanggulangi Kejahatan dalam Islam, (Jakarta: Rajawali Press,1997), 24. 
memikirkan alasan rasional ('illah) yang ada dibalik bentuk-bentuk pidana tersebut.

Bahkan menurut Quthb Lebih dari itu, khususnya dalam hal pidana hadd, argumen yang lebih khusus lagi dari para juris Muslim ini adalah bahwa hukuman yang berat itu memang harus dilakukan karena sesuai dengan perintah Allāh SWT. Karenanya, menurut mereka, apapun bentuk hukuman itu tetaplah harus dijalankan apa adanya. ${ }^{47}$ Dengan mendasarkan pada jenis-jenis pidana dalam $\underline{h} u d \hat{u} d$ -baik fuqaha klasik maupun kontemporer-- tidak menampik kerasnya pidana dalam kategori $\underline{h} u d \hat{u} d$. Menurut mereka hal ini bisa dipahami dari $\underline{h} u d \hat{u} d$, yaitu untuk memberi efek jera pada pelaku lain agar tidak melakukan kejahatan yang sama di lain waktu. 48

Pada era kontemporer, lahirnya pandangan tentang kekerasan hukuman (stigma) dalam $\underline{h u d \hat{u} d}$ tampaknya lebih dipengaruhi oleh fenomena dominannya bentuk pidana fisik atau badaniah di dalamnya. Hampir semua bentuk hukuman untuk perbuatan pidana yang disebutkan dalam sumber teks Islam memang berkisar pada hukuman-hukuman yang bersifat fisik, seperti dipotong tangannya, dicambuk, dilempar dengan batu (dirajam) dan lain-lainnya. Hal inilah sesungguhnya yang tampaknya menjadi stigma akan kekejaman terhadap bentuk-bentuk hukuman dalam Islam. Pertanyaannya sekarang adalah apakah bentuk-bentuk hukuman semacam ini bersifat tauqifi yang harus diimplementasikan harus sama persis sebagaimana ketentuan Al-Qur'an atau hadis Nabi $(\underline{h} u d \hat{u} d)$ menuntunkannya? Atau sejatinya dimungkinkan adanya perubahan bentuk hukuman yang semula hanya terfokus pada hukuman fisik kepada bentuk siksaan baru yang lebih bersifat nonfisik. Kontroversi dan diskursus terkait teori kekerasan hukuman ini tidak hanya terjadi di kalangan umat Islam saja, para ahli filsafat hukum Barat juga memperdebatkan hal yang sama. ${ }^{49}$

Gagasan al-Ashmawi mengisyaratkan bahwa ketentuan $\underline{h} u d \hat{u} d$ sejatinya bukan harga mati yang selalu representatif untuk segala ruang dan waktu. Hal senada juga dikemukana Fazlur Rahman --

47MuhammadQuthb, Manhaj al-Tarbiyyah al-Islamiyyah (Beirut: t.p., 1967), 231-234.

${ }^{48}$ Mashood A. Baderin, International Human Rights and Islamic Law, (Oxford University Press, Oxford, 2003) 79.

${ }^{49}$ Virginia Mackey, Punishment in the Scripture and Tradition of Judaism, Christianity and Islam (New York: National Interreligious Task Force on Criminal Justice, 1983). 
guru besar studi Islam University of Chicago asal Pakistan-- yang memberikan analisis pengembangan hukum pidana Islam dari akar kata hadd itu sendiri. Ia mengungkapkan dengan kalimat:

"the idea of a "limit" (which separates one thing from another) is, therefore, the most basic meaning of hadd...it is very idea that has been repeatedly expressed in the Quran in a moral sense when the Quran speaks of hudîd Allāh or "limit" (prescribed by) God...".50

Tujuan pemidanaan dalam Islam bukan hanya sebagai retribution (pembalasan) semata, tetapi memiliki tujuan mulia lainnya sebagai deterrence (pencegahan) dan reformation (perbaikan), serta mengandung tujuan pendidikan (al-tahdzîb) bagi masyarakat. Tujuan pemidanaan tersebut merupakan satu kesatuan utuh dalam penerapan hukum pidana Islam untuk mewujudkan kemaslahatan manusia. ${ }^{51}$

Pendapat dan rumusan di atas juga didukung oleh An-Na'im. Ia mengemukakan bahwa bentuk-bentuk sanksi (al-'uqûbât) pidana dalam hukum pidana Islam bukanlah satu-satunya cara untuk menegakkan moralitas dan kebaikan umum. An-Na'īm menegaskan bahwa hukum pidana Islam berpotensi menimbulkan kejahatan kemanusiaan dan pelanggaran hak asasi manusia bila tidak dikontekstualisasikan. Namun demikian, karena tidak ada ayat yang dapat dijadikan landasan untuk menentang ayat-ayat yang sangat eksplisit dan tegas yang menetapkan $\underline{h} u d \hat{u} d$, maka tidak ada cara yang sah untuk menghapus dan membatalkan hukuman-hukuman tersebut sebagai bagian dari hukum pidana Islam, kecuali hanya membatasi aplikasinya dalam praktik. ${ }^{52}$

Salah satu kajian kritis terkait ini dapat ditelusuri melalui Q.S. al-Nisa' 5:13-14. Dengan mencermati penggalan ayat "tilka h̆ udîd Alläh" yang menegaskan bahwa pihak yang memiliki otoritas untuk

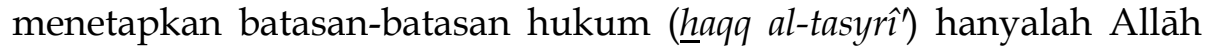
semata. Sementara Nabi Muhammad, kendati berkapasitas sebagai

\footnotetext{
50Fazlur Rahman, Islam and Modernity; Transformation of an Intellectual Tradition, (Chicago USA: The University of Chicago Press, 1982), 237.

51Satria Efendi M. Zein, Piinsip-prinsip Dasar Hukum Jinayat dan Permasalahan Penerapannya Masa Kini, Mimbar Hukum, Nomor 20 tahun VI (Jakarta: Al-Hikmah, 1995) 32.

${ }^{52}$ Abdullahi Ahmed An-Na'im, Toward an Islamic Reformation: Civic Liberties, Human Right and International Law (Syracuse: Syracuse University Press, 1990), 141-144.
} 
Nabi dan Rasul, sejatinya otoritas yang dimilikinya, tidak penuh dan posisinya adalah sebagai pelopor ijtihad dalam Islam. ${ }^{53}$ Hukum yang ditetapkan Nabi sejatinya lebih bersifat temporal-kondisional sesuai dengan derajat pemahaman, nalar zaman, dan peradaban masarakat pada waktu itu.

Terkait hukuman potong tangan pada Q.S. al-Maidah 5:38 mengenai hukuman pencurian, baik pencuri laki-laki maupun perempuan, dalam pandangan Syahrur, merupakan hukuman maksimum. Dengan demikian, maka hukuman untuk pencuri tidak mesti potong tangan tetapi tergantung pada kualitas barang yang dicuri dan kondisi saat itu. Bahkan potong tangan dan rajam dinilai tidak relevan apabila diterapkan di Indonesia. Potong tangan, rajam, dan cambuk, bukanlah tujuan hukum itu sendiri, melainkan sebagai instrumen untuk membuat pelaku pidana jera. Dalam pandangan Ibrahim, bila penjara bisa membuat para pelaku pidana menjadi jera, maka potong tangan tidak perlu dilakukan. Konstruksi hudûd juga berfungsi sebagai bentuk zawâjir. Sanksi-sanksi hukum dalam bidang kepidanaan ( $\underline{h} u d \hat{u} d)$ tersebut tidak berfungsi menambal dosa yang bersangkutan pelaku kejahatan (jawâbir). ${ }^{4}$

\section{Kesimpulan}

Berdasarkan pada analisis di atas, dapat disimpulkan bahwa diskursus hudûd dalam hukum Islam telah mengalami pergeseran paradigma (paradigm shift) dari waktu ke waktu. Mulai dari sumber utama: Al-Qur'an menggunakan terma hudûd secara luas, fleksibel, leluasa untuk segala bidang. Terma hudûd yang identik dengan bentuk-bentuk pidana (al-'uqûbût al-muqaddarah) sejatinya lebih merepresentasikan hasil baca para yuristik Islam (fuqahấ) atas tradisitradisi Nabi (Sunnah) serta produk dari epistemologi yang berbasiskan pada nalar tradisional yang didominasi oleh teks-teks keagamaan yang sering disebut nalar bayânî. Sebagai sebuah entitas

${ }^{53}$ Dikutip dari tulisan Burhanuddin, Artikulasi Teori Batas (Nazariyyah al Hudud) Muhammad Syahrur dalam Pengembangan Epistimologi Hukum Islam di Indonesia dalam buku Sahiron Syamsuddin, dkk. Hermeneutika Alqur'an; Madzhab Yogya, (Yogyakarta: Penerbit Islamika, 2003), 152.

${ }^{54}$ Lihat gagasan Ibrahim Husain, "Jenis-jenis Hukuman dalam Pidana Islam; Reinterpretasi terhadap Pelaksanaan Aturan" dalam Jamal D. Rahman (ed.), Wacana Baru Fiqh Sosial, 70 Tahun KH. Ali Yafie (Bandung: Mizan, 1997) 
hasil pemikiran para yuristik Muslim, eksistensi pidana hudûd merupakan produk pemikiran yang terbuka dari upaya pembaruan.

\section{Daftar Pustaka}

Abu Shahbah, Muhammad Ibn Muhammad, al- $\underline{H} u d \hat{u} d$ fi al-Islām wa Muqāranatuha bi al-Qawānin al-Wadl'iyyah (Kairo: t.p., 1973)

Abu Zahrah, Muhammad, al-Jarimah wa al-'Uqübah fi Figh al-Islam (t.tp: Dar al-Fikr al-'Arabi, 1973)

Ali al-Qunuwi, Qasim Ibn Abdillah Ibn Amir, Anis al-Fuqaha' fi Ta'rifat al-Alfazh al-Mutadawalah baina al-Fuqaha' (Jeddah: Dar al-Wafa', 1406)

al-'Asqalani, al-Hafizh Ibn Hajar, Bulugul Maram Min Adillatil Ahkam, (Beirut: Darul Fikr, 1998)

al-iIlmiyyah, t.th.)

al-'Azhīm Âbādi, Abu Thayyib Muhammad Syams al-Haqq, 'Aun alMa'būd Syarah Sunan Abū Dāwud (Madinah Munawwarah: Maktabah al-Salafiyyah, 1968 M/1388 H)

Asshiddieqy, Hasbi, al-Islam (Jakarta: Bulan Bintang, 1977)

'Audah, 'Abd al-Qadir, al-Tasyri al-Jina'i Muqaranan bi al-Qanun alWadl'i (Beirut: Dar al-Risalah al-Mu'assasah, 1996)

al-Bassam, Taisir 'ala-Allāh Min Syarh 'Umdah al-Ahkām (Beirut: Mathba'ah li Nasyr wa al-Dakwah, t.th)

al-Bustani, Butrus, Muñith al-Muhīth; Qāmùs Mutawwal li al-'Arabiyyah (Lebanon: Maktabah Lubnah, 1983)

al-Manāwī' 'Abd al-Ra'uf, Faidl al-Qadīr Syarh al-Jāmi' al-Shaghīr (Mesir: Makatabah al-Tijariyyah al-Kubra, $1356 \mathrm{H}$ )

Djazuli, Fiqh Jinayat: Upaya Menanggulangi Kejahatan dalam Islam, (Jakarta: Rajawali Press, 1997)

El-Awa, Mohammed S., Punishment in Islamic Law (Indianapolis: American TrusPublications, 1982)

Ibnu Muhammad al-Husaini, Taqi al-Din Abu Bakar, Kifāyat al-Akhyār fi Hill Ghāyat al-Ikhtishār (Beirut: Dar Kutub al-'Ilmiyyah, t.th.)

Ibnu Musa al-Hajawi, Syaraf al-Din Musa Ibn Ahmad, al-Iqna' fi Figh al-Imam Ahmad Ibn Hanbal (Beirut: Dar al-Ma'rifah, t.th) 
Ibnu Manzhur al-Ifriqi al-Mishri, Abu Fadl Jamal al-Din Muhammad ibn Mukram, Lisan al- 'Arab (Beirut: Dar al-Kutub al-'Ilmiyyah, 1992)

Ibnu Zakariya, Abu Al-Husain Ahmad bin Faris, Mu'jam Maqāyis alLughah, (Beirut: Dar-al-Fikr, 1979)

Ibrahim Husain, "Jenis-jenis Hukuman dalam Pidana Islam; Reinterpretasi terhadap Pelaksanaan Aturan" dalam Jamal D. Rahman (ed.), Wacana Baru Figh Sosial, 70 Tahun KH. Ali Yafie (Bandung: Mizan, 1997)

Kamali, Muhammad Hashim, Membumikan Syariah; Pergulatan Mengaktualkan Islam, terj. Miki Salman "Shariah Law; an Introduction" (Bandung: Mizan, 2013)

M. Zein, Satria Efendi, Piinsip-prinsip Dasar Hukum Jinayat dan Permasalahan Penerapannya Masa Klni, Mimbar Hukum, Nomor 20 tahun VI (Jakarta: Al-Hikmah, 1995)

Mashood A, Baderin, International Human Rights and Islamic Law, (Oxford University Press, Oxford, 2003)

Muhammad Quthb, Manhaj al-Tarbiyyah al-Islamiyyah (Beirut: t.p., 1967)

Musa Ibn Muhammad Ibn al-Milyani al-Ahmadi, Mu'jam al-Af'äl alMuta'addiyah Bi-Harfin, (Jeddah: Dar al-Nasyir, 2009)

Mushthafa, Ibrahim Anas, dkk., Mu'jam al-Wasith, (Teheran: Maktabah al-Ilmiyah: t.th.)

An-Na'im, Abdullahi Ahmed, Dekonstruksi Syari'ah; Wacana Kebebasan Sipil, HAM dan Hubungan Internasional dalam Islam Terj. Ahmad Suaedy dan Amirudin ar-Rany "Toward an Islamic Reformastion: Civil Liberties, Human Right and Internastional Law" (Yogyakarta: LKiS Group, 2011)

, Toward an Islamic Reformation: Civic Liberties, Human Right and International Law (Syracuse: Syracuse University Press, 1990)

al-Qusyairi, Muslim Ibn al-Hajjaj Abu al-Husain, Shahih $\underline{\text { Muslim, }}$ tahqiq oleh Muhammad Fu'ad 'Abd al-Baqi (Beirut: Dar Ihya' al-Turats al-'Arabi, t.th.)

al-Raghib al-Ashfanani, Mufradāt Alfāzh Alqur'ān, (Damaskus: Dar alQalam, 1412 H./1992 H)

Rahman, Fazlur, "The concept of hadd in Islamic law." dalam Islamic Studies Journal, edisi 4:237-52., 1965) 
Rahman, Fazlur, Islam and Modernity; Transformation of an Intellectual Tradition, (Chicago USA: The University of Chicago Press, 1982)

Roberts, Robert, The Social Laws of The Qoran, Consideres and Compared With those of The Hebrew and Other Ancient Codes (New Delhi: Kitab Bhavan, 1977)

al-Sajastani, Abu Dawud Sulaiman Ibn al-Asy'ats, Sunan Abu Dawud (Beirut: Dar al-Kitab al-'Arabi, t.th.)

al-Sa'dī, 'Abd al-Rahmān Ibn Nashir, Bahjat al-Qulūb al-Abrār wa Qurratu 'Uyūn al-Akhyār Fi Syarh Jawāmi' al-Akhbār (Saudi Arabia: Kementerian Wakaf dan Dakwah, $1423 \mathrm{H}$ )

al-Shan'ani, Muhammad bin Ismail al-Kahlani, Subul al-Salam, (Bandung: Dahlan, t.th,)

al-Syarbaini, Muhammad Khathib, Mughni al-Muhntāj ilā Ma'rifati Ma'āni al-Alfäzl al-Minhāj (Beirut: Dar al-Fikr, t.th.)

al-Syaukānī, Muhammad Ibn 'Ali Ibn Muhammad, Nail al-Authār Min Ahādits Sayyid al-Akhyar Syarh Muntaqa al-Akhbar (Damaskus: Idarah al-Thiba' ah al-Muniriyyah,1966)

al-Sya'rani, 'Abd al-Wahhab Ibn Ahmad al-Anshari, Mizan al-Kubra (Beirut: Dar al-Kutub al-illmiyyah, t.th.)

al-Tirmidzi, Muhammad Ibn 'Isa Abu 'Isa, al-Jami' al-Shahih Sunan alTurmudzi, ditahqiq oleh Ahmad Muhammad Syakir dkk (Beirut: Dar Ihya al-Turats al-'Arabi, t.th.)

Sabiq, al-Sayyid, Figh al-Sunnah, Mesir: Maktabah wa Mathba'ah, 1974)

Sahiron Syamsuddin, dkk. Hermeneutika Al-Qur'an; Madzhab Yogya, (Yogyakarta: Penerbit Islamika, 2003)

Salam, Abdul, Figh Jinayat: Hukum Pidana Islam, (Yogyakarta: Ideal, 1990)

Sulaiman, Muthi'ullah Dakhilullah al-Shurhaidi al-Luhaibi, al-'Uqubat al-Muqaddarah wa Hikmatu Tasyri'iha fi Dlaui al-Kitab wa alSunnah (Jeddah: Tihama, 1983)

Virginia Mackey, Punishment in the Scripture and Tradition of Judaism, Christianity and Islam (New York: National Interreligious Task Force on Criminal Justice, 1983)

Zahrah, Abū, al-'Uqūbah; al-Jarimah wa al-'Uqūbah fì al-Islām (Kairo: Dār al-Fikr al-`Arabī, 1998) 